\title{
THE ORGANIZATION OF AFRICAN UNITY IN THE SEVENTIES
}

\author{
by ZDeneK Čnvenka
}

Africa ended the sixties by losing many of her illusions about the early attainment of the principle aims of the Organization of African Unity: the liberation of the remaining colonies and the liquidation of all forms of racial oppression ${ }^{1}$. It should be recalled that it was the common stand on colonialism and apartheid that brought thirty-one leaders of African states to agree on holding the Summit Conference of Heads of State and Government of Independent African States in Addis Ababa from 23 to 26 May 1963 and to put their signature to the Charter of the OAU. Every one of those assembled leaders ${ }^{2}$ must have had his reservations about the Charter and its political consequences. However, no objection against any of the provisions of the Charter could have been strong enough to justify a withdrawal from the signing ceremony. Any leader who would have dared to do so would have run the risk of being blackballed as a traitor to Africa's united camp, fighting colonialism and apartheid. In the face of the resolution, all personal, ideological and regional differences fell away and all 31 Heads of State and Government present agreed to become members of one allAfrican organization. They each wanted to show the world that the task of freeing the African continent from colonialism and apartheid was sufficiently strong to bind them together in the Organization of African Unity ${ }^{3}$.

The African unity achieved in Addis Ababa in 1963, however, was soon exposed to severe strains and crises, such as the armed conflict between Algeria and Morocco which erupted barely four months after the Charter was signed ${ }^{4}$, and

\footnotetext{
1 Article II of the Charter of the Organisation of African Unity lists as one of the purposes of the Organisation to eradicate all forms of colonialism from Africa". The liquidation of racial oppression in Africa is closely linked with the colonial issue. The white minority regimes in Rhodesia and South Africa which both practice racial discrimination policies known as "apartheid" are regarded by the independent Africa as an alien rule. The OAU Charter refers to this problem in general terms in independent Afrea connection with the reaffirmation of the adherence to the Universal Declaration of Human Rights in
the Preamble and in Article II 1(e). Far more outspoken is the Resolution on Apartheid and Racial Discrimination adopted jointly with the OAU Charter in Addis Ababa on 26 May 1963. There the signatory States are "unanimously convinced of the imperious and urgent necessity of co-ordinating and intensifying their efforts to put an end to the South African Government's criminal policy of apartheid and wipe out racial discrimination in all its forms".

2 The following are the founding members of the OAU: Algeria, Burundi, Cameroun, Congo, Zaire, Ivory Coast, Dahomey, Ethiopia, Gabon, Ghana, Guinea, Upper Volta, Liberia, Libya, Madagascar, Mali, Morocco, Mauretania, Niger, Nigeria, Egypt, Central African Republic, Twanda, Senegal, Sierra Leone, Somalia, Sudan, Tanzania, Chad, Tunisia and Uganda.

3 Zdenek Cervenka: "The Organisation of African Unity and Its Charter", London: Ch. Hurst, 1969, pp. 26-27. For a general discussion of the OAU see also Jon Woronoff: "Organizing African Unity", Metuchen, New Yersey: The Scarecrow Press, 1970, Boutros-Ghali: "The Addis Ababa Charter". In: International Conciliation, New York, 1964, No. 546, T. O. Elias: "The Charter of the Organization of African Unity". In: American Journal of International Law, Washington, 1965, Vol. 59, No. 2, April, pp. 243-267, Immanuel Wallerstein: "The Early Years of the OAU: The Search for Organisational April, pp. 243-267, Immanuel Wallerstein: “The Early Years of the OAU: The Search for Organisational
Preeminence". In: International Organisation, Boston, 1966, Vol. 20, No. 4, pp. 774-787, Suzanne Preeminence". In: International Organisation, Boston, 1966, Vol. 20, No. 4, P. 774-787, Suzanne 1967, October, pp. 20-39.

4 The armed conflict between Morocco and Algeria erupted in the second week of October 1963, barely four months after the Charter emphasizing the principle of "peaceful settlement of disputes" had been signed. Morocco claimed a large area of Algerian held Sahara, greater in size than the present territory signed. Morocian kingdom. The presence of important mineral resources, particularly oil, in the of the Morroccan kingdom. The presence of important mineral resources, particularly oil, in the progress Emperor Haile Selassie of Ethiopia and President Modibo Keita of Mali assumed the role of peace-makers. At Bamako they made both Algeria and Morocco consent to a common agreement, the cessation of hostilities and the finding of a solution to the problem through negotiations within the OAU framework. For the detailed study of the Algerian-Morocco armed dispute see Patricia Wild, "The Organisation of African Unity and the Algerian-Morocco Border Conflict". In: International Organisation, Boston, 1966, Vo. XX, No. 1, pp. 18-36.
} 
in particular the Unilateral Declaration of Independence by the white minority regime in Rhodesia on 11 November $1965^{5}$, which constituted a potential threat to the very existence of the Organization.

All those, however, who predicted the end of the OAU were disappointed. The Rhodesian crisis made African leaders realize that they could not expect any help from outside but that above all they must rely on themselves. Awareness of the hard political realities in Africa was magnified by the series of military coups d'etat which brought a change of government in nearly twenty African States over a span of only six years - between 1963 and 19696. The overthrow of President Kwame Nkrumah of Ghana in February 1966 was in many respects a turning point in the OAU's history, resulting in Africa's withdrawal from the international scene. Though Dr. Nkrumah's vision of the African continental government proved to be unrealistic, at least in his time, he had a profound effect on the continent which in many ways has become permanent. No African independent state has been unaffected by the cause of African Unity to which he dedicated Ghana's foreign policy. The Organization of African Unity would not have existed but for his advocacy, although the Organization, once established, chose a different path in the direction of African Unity from that envisaged by Kwame Nkrumah. The impact of his overthrow twice plunged the Organization into turmoil. The first time was in February 1966 when seven African delegations walked out of the Conference of the Council of Ministers of the OAU in Addis Ababa in protest against the seating of the Ghanaian delegation sent by the National Liberation Council of Ghana. The second time, on 29 October 1966, a Guinean delegation led by the Minister of Foreign Affairs, Dr. L. Beavogui, was detained in Accra on the way to the OAU Conference in Addis Ababa. Although the reason given for the detention was retaliation for the alleged keeping of 85 Ghanaians in Guinea, the deposed President Nkrumah who had been granted asylum in Guinea, was the true cause for the dispute. Only joint efforts by Presidents Nasser, Tubman, Nyerere, Modibo Keita and Emperor Haile Selassie prevented a further deepening of the crisis which temporarily paralysed the functioning of the OAU.

Apart from providing ammunition for those who believed in the incapability of Africans governing themselves, the military coup in Ghana and the outbreak of the Nigerian civil war in 1967 has intensified the trend of concentration of all African states on their domestic policies. This distinct preference for internal problems, both political and economic, has become the dominant feature of the African political scene, and it was fully reflected in the businesslike discussion and the emphasis on economic issues at the subsequent Summit Meetings of the OAU?.

5 Following the Unilateral Declaration of Independence by the white minority regime in $\mathrm{Rhodesia}$ on 11 November 1965 the Extraordinary Session of the Council of Ministers of the OAU was convened to Addis. Ababa on 3 December 1965. In one of the most strongly worded resolutions in the OAU history the Council of Ministers took a decision that "if the United Kingdom does not crush the rebellion and restore law and order, and thereby prepare the way for majority rule in Southern Rhodesia by 15 December, 1965, the Member States of the OAU shall sever diplomatic relations on that date with the United Kingdom". When eventually only nine countries out of the total membership of thirty-six did so, the annoyance of the nine with those who did not made the break rankle for a long time. President Nyerere of Tanzania described the refusal of the States which did not implement the Council of Ministers resolution as "having dealt a death blow to the Organisation".

6 For a detailed analysis of the military coups in Africa see Ruth First, "Barrel of the Gun", London: The Penguin, 1970, 513 pages.

7 Hence, for example, the ladk of support for Somalia's call for an extraordinary meeting of the OAU in June 1967 to consider the Middle East situation and to condemn the "Israeli aggression against the UAR*. For the majority of the OAU members at that time, the Egypt-Israeli war in June 1967 was not an African affair at all. It was felt that it should be primarily if not exclusively the concern of the United Nations. The change of this attitude took place in 1971 as pointed out further on. 
The decline of Africa's militancy still continued when she entered the seventies. At this time South Africa launched its "outward policy" by virtue of which she had hoped to break Africa's united front against apartheid and to penetrate economically into the territories north of the "safety belt" of southern Africa. There are two main reasons for South Africa's Prime Minister John Vorster's "verligte" (outward) policy: security and the economy.

Firstly, there is the mounting threat of guerrilla operations, stimulated by countries bordering South Africa's sphere of influence, namely, Zambia and Tanzania ${ }^{8}$. Anxiety over guerrilla activity led to: South Africa's unavailing efforts to prevent the construction of the new Botswana-Zambia road; violations of Zambian airspace; attempts to persuade President Kaunda to compromise on the "dialogue" issue. Premier Vorster seriously believes that if President Kaunda's position can be undermined, the O.A.U. will split, and guerrilla activity will cease. Secondly, most important, however, are the economic considerations though they too are closely linked with South Africa's political ambitions. In view of the continuing deterioration of South Africa's economy, the first priority is now to increase exports ${ }^{9}$. South Africa lacks the advantages of the exports on the scale available to her European competitors, since her domestic market is artificially limited by skin colour. Higher incomes are reserved for whites, who constitute less than $20 \%$ of the population. Average African incomes are little more than $\$ 6$ per month. Separated by vast distances from major world markets, South Africa suffers the additional disadvantage of high transport costs. Manufacturing costs are also relatively high: the implementation of apartheid has led to a shortage of skilled workers. South Africa therefore looks to the African continent for new trading opportunities. Thus from the economic point of view the essence of the outward policy is to create a "prosperity sphere" comprising South Africa, Angola, Mozambique, Lesotho, South West Africa - Namibia - Swaziland, Botswana, Malawi, Rhodesia and Zambia by means of integration of infrastructure, stepping up trade and investment, drawing up a single monetary and fiscal policy and creating a "labour pool". The labour pool is to be composed of all "nationals", that is Africans of the various countries who will work on the permanent or long term basis in the "developed areas" that is, in other words, in South Africa and Rhodesia. The whole idea is, of course, nothing else but the economic extension of apartheid ${ }^{10}$.

The creation of the "prosperity area" would, of course, have a tremendous economic advantage for South Africa. South Africa's economic power - expressed in terms of trade and aid expansion in Africa - would effectively give her a controlling influence over the development of the enormous, unexploited deposits of strategic minerals of the whole African continent. She would gain the

\footnotetext{
8 This threat is taken very seriously indeed. Its scale was incautiously admitted by Police Minister S. L. Muller last March, when he said that during the last two years 13 policemen had been killed and 369 injured while on active duty against "terrorists". The primary purpose of the defence forces was long ago defined as the maintenance of internal security. During the past decade the defence budget has soared rapidly - from £ 22 millions in 1960/61 to over $£ 150$ millions in 1970/71 and a projected $£ 185$ millions in $1971 / 72$.

9 In 1970 , South Africa had the worst balance of payments deficit in her history - $\$ 460$ millions. The trend has continued into 1971. The adverse trade gap for the first three months of 1971 was $\mathbf{2} 233$ million, compared with $\$ 109$ million for the corresponding period of 1970 . Foreign exchange reserves stood at only \& 470 millions at the turn of the year. The figures show, not a temporary, cyclical deterioration, but a fundamental imbalance in the nation's economy. M. S. Christie: "Economic Badkground to Dialogue", in: Africa, an international business, economic and political monthly, London 1971, No. 2, July, p. 20.

10 Ruth Weiss, "South Africa: The Grand Economic Design", in: Africa Contemporary Record, Annual Survey and Documents 1970-71, edited by Colin Legum, London: Rex Collings, 1971, Pp. A11-A17.
} 
mass markets for her industries by co-operating with the independent African states not only in southern but also in central and northern Africa. She would strengthen her position in pursuing the goal summed up by South Africa's Prime Minister John Vorster, in the following words:

"We are of Africa, we understand Africa and nothing is going to prevent us from becoming the leaders of Africa in every field."11

The foundations for South Africa's grand economic design were already laid, owing to the co-operation of Malawi, Rhodesia, Portuguese colonies Angola and Mozambique as well as of Lesotho and Swaziland, and to a lesser degree Botswana. Zambia is the only one, but very hostile opponent of the scheme in the area. The important overture to the "dialogue" was the move by Dr. Banda who shattered the OAU's uncompromising stand on the policy of apartheid by announcing on 10 September 1967 the establishment of formal diplomatic relations between Malawi and the Republic of South Africa. It took place almost concurrently with the Resolution on Apartheid and Racial Discrimination adopted at Kinshasa in September 1967, which considers 'that the continued existence of apartheid and racial discrimination constitutes an odious crime against humanity and represents a grave menace to peace and security', which condemns the political, economic and military collaboration of the Western powers with South Africa and, finally, requests 'all African States to exercise a most vigilant control of their boycott on South African products'. Reactions in Africa to Dr. Banda's move ranged from the sharp criticism by Zambia, requesting that Malawi be expelled from the OAU, to mere regrets from Mauritania and even understanding from some others, notably Chad, Ghana and Ivory Coast. This indeed fitted the main elements of South Africa's foreign policy.

If South Africa is to break out of the isolation in which international condemnation of apartheid has placed her, she must show that the nations which contrived that isolation - the independent states of Africa - are now prepared to accept her unconditionally. When Mr. Vorster sent as his Ambassador to Paris Mr. H. Burger, formerly head of the Africa Department of South Africa's Foreign Ministry, he was not simply concerned with Franco-South African Problems, but also with the influence that France could bring to bear on members of the OCAM.

Significantly, South Africa does not seek acceptance on equal terms by other African states. Mr. Vorster, while working towards a dialogue, could not propose it himself. It had to come to South Africa from an African. The proposal for the "dialogue" with South Africa, made by President Houphouet Boigny on 4th November 197012, showed how successful the South Africans were with their outward policy. President Houphouet Boigny advocates the establishment of diplomatic and economic relations with South Africa, believing that the presence of diplomatic and trade missions of independent African states in South Africa, and the mutual contacts, will eventually cause the "change of heart" of the South African white minority and bring about the erosion of apartheid. His statement led to a controversy that has seriously endangered African solidarity against South Africa. At present President Houphouet Boigny is supported by

\footnotetext{
11 ibid.

12 President Houphouet Boigny's statement on the “dialogue” appeared in Jeune Afrique, Paris, November 17, 1970. No. 515.
} 
seven other African states - Malagasy, Malawi, Rwanda, Uganda, Gabon, Chad and Dahomey. In the long run he may yet "capture" Togo and the Central African Republic. Ghana supports dialogue but takes a different stand on objectives and strategy. What will be the attitude of the new regime which succeeded that of Dr. Kofi Busia, overthrown by a military coup on 13th January 1972 is, at the time of writing this article, difficult to say. The views of the advocates of the "dialogue" could be summed up as follows:

a) The armed struggle has failed.

b) The African states do not possess the military and economic resources to challenge South Africa decisively.

c) Meanwhile, South Africa feeling itself threatened may be incited into taking the offensive.

d) The policy of political and cultural isolation will not eliminate apartheid. Instead, "isolation only seems to consolidate national unity and increase national resolve to maintain and defend the regime".

e) The trade embargo cannot succeed. Many countries, including some African countries, have stated that they must continue to trade with South Africa.

f) There are moderate forces within South Africa, black and white, with whom contacts should be made. These, as Dr. Busia has put it, are "potential allies", who deserve to be cultivated.

g) The fact that African states are holding a dialogue with the South African Government will encourage moderate white opinion and influential business pressure groups to seek an accord with the black majority for the purpose of changing the apartheid policies of the present regime, "or else of changing the reactionary regime itself by methods which only those who live in the country can legitimately use"13.

The publicity which the "dialogue" has been receiving in the mass media of the Western World is, however, completely out of proportion to the actual stand of the majority of the independent African states. Indeed, certain sections of the world press, notably in France, gave rise to the impression that Africa was left with no other alternative but to accept it. As a matter of fact it was the challenge of the "dialogue policy" which awoke the sense of urgency in the African leaders to mount a counter-offensive against South Africa. In this respect the meeting between Major General Gowon, the Head of the Military Government of Nigeria, and Emperor Haile Selassie of Ethiopia which took place from 4 to 8 May 1971 was of particular significance. It laid down the rules according to which the "dialogue policy" was to be treated by the Organisation of African Unity itself. The Emperor's authority carries a weight with the leaders of independent African States which can not be matched by any other African statesman. Major General Gowon's prestige stems not only from his ability, with which he has assumed his role of the Head of State of Africa's largest and most populous state,

13 Peter Enahoro, "Dialogue", in: Africa, an international business, economic and political monthly, London, 1971, No. 2, July, p. 15. 
but also from the military might of Nigeria's 100,000 men strong army. In their joint communiqué of 8 May 1971 they stated in clear terms that the only basis for the "dialogue" with South Africa could be the Lusaka Manifesto. Speaking at a banquet in his honour, Major General Gowon said: "It will be a great betrayal, if we only pay lip service to the cause of liberation of the people of South Africa or if we assume that we can restore their dignity by bargaining on economic or other selfish grounds with their oppressors." He added: "Nigeria will not be a party to any dialogue with those whose only aim is to divide our ranks and subjugate our brothers, forever, in servitude and degradation."14

Similar unity of views was reached during General Gowon's visit to Kenya four days later with Kenya's President Jomo Kenyatta. The communiqué of 12 May expressly condemns the dialogue stating that "there could be no meaningful dialogue which was not based on human equality and dignity as envisaged in the Lusaka Manifesto"15. It has become obvious that the mere rejection of the "dialogue" would not suffice unless a counter-offensive against the outward policy of South Africa were launched. The Administrative Secretary General of the OAU, Diallo Telli, in his message marking the 8th anniversary of the organisation recalled that "Since it was established, the Organisation of African Unity's prime and urgent objective has been the total liberation of our Continent from all forms of foreign occupation, oppression and exploitation" and concluded by saying: "Our ardent desire at the OAU Secretariat is that... all African leaders would transcend their differences in the greater interest of Africa, close their ranks and, conscious of the common danger threatening them, adopt for our collective honour, a more dynamic and effective new strategy for the liberation of our Continent from the last humiliating vestiges of colonial occupation and racial oppression ${ }^{16}$."

The revival of the spirit of unity became evident in particular at the Summit Meeting of the OAU which was held from 21 to 23 June 1971 in Addis Ababa. It was preceded by the resumption of the 16th meeting of the Council of Ministers of the OAU which had been adjourned in March. The highlight of the meeting was the successful solution of the issue of the legitimacy of Uganda's representation at the Council meetings claimed both by the delegation of the deposed President Milton Obote and by the delegation of the new military ruler ${ }^{17}$. The record length meeting of the Council, which began its

14 Quoted in the article "Dialogue With South Africa - The Great African Debate" by David A. Talbot in the Ethiopian Herald, Addis Ababa, 1971, May 9.

15 Visit of His Excellency Major-General Yakubu Gowon, Head of the Federal Military Government, Commander-in-Chief of the Armed Forces of the Federal Republic of Nigeria, to the Republic of Kenya: May 8-12, 1971, Lagos: Federal Ministry of Information, Press Release No. 466, May $12,1971$.

16 Message of the Administrative Secretary-General on the occasion of the eighth anniversary of the establishment of the Organisation of African Unity, Press Release of the OAU Secretariat, 25th May, 1971.

17 Soon after President Milton Obote was overthrown on January 25, 1971, by a military coup led by General Amin, the regular meeting of the Council of Ministers of the OAU was convened to Addis Ababa on 26 February 1971. The Ministerial Council, unable to resolve the question of Uganda representation, that is whether to accept the credentials of the delegation sent by the deposed President Obote who found refuge in Tanzania or by he new military regime, adjourned sine die on 1 st March 1971 and referred the matter to the OAU Summit scheduled for June. The decision was without precedent in the history of the OAU. The situation was of course rather complicated by the fact that Kampala was to be the site of the 1971 meeting of both the Council of Ministers and of the Assembly of Heads of State and Government and that all the top OAU officials - Current Chairman of the Council of Ministers Omar Arteh of Somalia and the Administrative Secretary General Diallo Telli - made known their strong disapproval of the overthrow of President Milton Obote. The time, however, worked in favour of General Amin and the rule that the recognition of the new government was for each sovereign state to decide and should not be of concern to the organisation eventually prevailed. It was felt, how ever, that holding the conference in Kampala would inevitably give rise to a showdown between General Amin's friends and enemies, so that it would be better to hold it on the neutral ground of the OAU's headquarters in Addis Ababa.

Following an intense diplomatic activity in which Nigeria played an outstanding role as conciliator between Uganda and her adversaries, notably Tanzania, President Kaunda in his capacity as the current chairman of the OAU wrote to all member States proposing that "it would be in the highest interest of 
work on 11 June, ended by the statement of its Chairman, Omari Arteh, the Foreign Minister of Somalia, who said that, "Whatever differences we may have, the ultimate goal is one - African Unity". Indeed the unity was manifested twenty-four hours later, when the Council began its deliberation of the agenda for the Summit Conference. The prevailing mood in respect of the "dialogue" was already amply shown in the debate on the wording of this item on the agenda of the Council. The proposal of the Ivory Coast to have the matter inscribed as "peace through neutrality" was defeated in favour of the Tanzanian proposal "The principles of the OAU, The Lusaka Manifesto, Dialogue and future strategy of Africa"18. The walk-out of the Ivory Coast delegation and the decision of Upper Volta, Togo, Dahomey and Gabon not to participate in the debate on the matter, hat not blunted the sharpness of "The Declaration of the Question of Dialogue". It was adopted by 27 votes against 4 (Lesotho, Madagascar, Swaziland and Malawi) and two abstentions (Dahomey and Niger) with Ivory Coast, Upper Volta and Gabon not taking part in the voting and the other members of the OAU being absent (Uganda, Central African Republic, Republic of Zaire and Mauritius). In the Declaration, the Council rejected the "dialogue with South Africa", describing it as a "manoeuvre by that regime and its allies to divide African States, confuse world public opinion, relieve South Africa from international ostracism and isolation and obtain an acceptance of the status quo in South Africa".

The Declaration reiterates the commitment to the principles and purposes of the OAU Charter and points out that the Lusaka Manifesto is the only possible basis for any meaningful solution to the problems of apartheid, racial discrimination and colonialism in Africa. Should there be any dialogue at all, then, according to the Declaration, "it should appropriately be commenced only between the minority racist regime of South Africa and the people they are

\footnotetext{
the OAU" to convene the 8th Session of the Assembly of Heads of State and Government on 21st June 1971 in Addis Ababa and the session of the Council of Ministers ten days earlier, 11th June in the same place". As a result 33 Heads of State and Government expressed themselves in favour of holding the meeting in Addis Ababa, and accepted the dates. Uganda accused President Kaunda of violating the OAU Charter on the grounds that in order to change the place of meeting the correct procedure was to convene an extraordinary session of the OAU which is the only competent body to take a decision on the matter. The Charter, however, does not specify how exactly the necessary majority is to be obtained and President Kaunda by securing an express consent of a majority of more than two thirds acted in full conformity with the Charter. - It was understood that at first the Council of Ministers would resume its 16th meeting which was adjourned in February, on 11th June 1971. The 17th Session was scheduled for 15th June and was to be followed by the meeting of the Assembly of Heads of State and Government on 21st June.

18 "The Lusaka Manifesto on Southern Africa" is a joint statement agreed upon by representatives of Burundi, Central African Republic, Chad, Congo Republic, Zaire, Ethiopia, Kenya, Rwanda, Somalia,
Sudan, Tanzania, Uganda and Zambia at the Conference of East and Central African States in April, 1969. It was endorsed by the Assembly of Heads of State and Government of the OAU the same year and considered by the General Assembly of the United Nations, which refered to it in its resolution 2505 (XXIV) of 20th November 1969.

The Manifesto sums up the stand of African countries towards South Africa in the following way: "Our stand towards Southern Africa thus involves a rejection racialism not a reversal of the existing racial domination. We believe that all the peoples who have made their homes in the countries of Southern Africa are Africans, regardless of the colour of their skins; and we would oppose a racialist majority government which adopted a philosophy of deliberate and permanent discrimination between its citizens on grounds of racial origin. We are not talking racialism when we reject the colonialism and apartheid policies now operating in those areas; we are demanding an opportunity for all the people of these States, working together as equal individual citizens, to work out for themselves the institutions and the system of government under which they will, by general consent, live together and work together to build a harmonious society."

On the question of negotiating with South Africa it states: "We would prefer to negotiate rather than On the question of negotiating With South Africa it states: We would prefer to negotiate rather than
destroy, to talk rather than kill. We do not advocate violence, we advocate an end to the violence against human dignity which is now being perpetrated by the oppressors of Africa. If peaceful progress to emancipation were possible, or if changed circumstances were to make it possible in the future, we would urge our brothers in the resistance movements to use peaceful methods of struggle even at the cost of some compromise on the timing of change. But while peaceful progress is blocked by actions of those at present in power in the States of Southern Africa, we have no choice but to give to the peoples of those territories all the support of which we are capable in their struggle against their oppressors".
} 
oppressing, exploiting and suppressing". Perhaps the most important provision of the Declaration has been the clearly stipulated obligation demanding that "no Member State of the OAU would initiate or engage in any type of activity that would undermine or abrogate the solemn obligations and undertakings to the commitments in the Charter", and that any such action could be taken by the member State only "with the guidance, consent and approval of the Organization". In other words, the right to independent opinion and to the independent foreign policy of each member State does not apply to the "dialogue" qualified by the Declaration as the policy contrary to the very purposes and principles of the OAU Charter. The Declaration made it clear that from now on any State pursuing the policy of "dialogue" is acting contrary to the principles of the Charter and defying an expressly and strongly formulated opinion of the qualified majority of the OAU members. The consequences would be an increased isolation which, in the long run, may not be much different from a position of a State expelled from the community of independent African States.

Defying the majority view of the OAU, President Houphouet Boigny said in a broadcast on 1 July 1971, that the Ivory Coast did not consider itself bound by the Declaration on dialogue and declared that he would continue with his policy ${ }^{19}$. Although assured of the support by President Banda of Malawi20, the Central African Republic and understandably by Lesotho, some of his other supporters, for example Ghana, have become more cautious ${ }^{21}$. Whether the advocates of "dialogue" will eventually break away from the OAU in further pursuance of their policy remains to be seen. So far their views have produced a unifying rather than a dividing effect on the OAU, at least at present.

Concurrently with its deliberation on the "dialogue issue" the supreme organ of the Organisation of African Unity, the Assembly of Heads of State and Government, devoted most of the time of the June 1971 session to the new strategy for the liberation of Africa. President Senghor called on the members to double or even treble their contributions to the liberation movements. His appeal was seconded by President Abidjo of the Cameroun. Major General Gowon called for setting a time limit of three years during which at least one colony should be liberated ${ }^{22}$. The importance attached by the Assembly to the liberation struggle was also shown in the invitation of Amilcar Cabral, the leader of the liberation army in Guinea-Bissau to address the final session of the OAU. Cabral's special

19 Radio Abidjan, of July 1, 1971, quoted by Africa Research Bulletin, London, Vol. 8., No. 7, August 1971 , p. 2156.

20 After the visit of President Banda of Malawi to South Africa on 16th August 1971, to become the first African Head of State to visit South Africa, Radio Johannesburg on 23rd August 1971 triumphantly stated: “Any obstacles that other African leaders may have felt stood in their way will have been removed by the success of last week's dialogue and contacts within South Africa between black and white at the highest level. The dialogue pattern in Southern Africa is now firmly established and has become a permanent feature of life that will be expanded and consolidated. Already plans are being made for the South African President, Mr. J. J. Fouché, to visit Malawi. The dialogue between South Africa and West African nations is the next development to be expected. The overtures have already been made. . ." ibid. pp. 2190-2191.

21 The Government newspaper, the Ghanian Times, called President Banda a "Don Quixote" who was doing a very grave disservice to the fight against apartheid. His "tirades" against the rest of Africa and the OAU during his visit were uncalled for. Africa Research Bulletin, London, Vol. 8, No. 8, September 1971, p. 2191.

22 Similarly, the Nigerian press took up the issue with unpreceded militancy. Commenting on the issue of apartheid which dominated the OAU Summit Conference, The Daily Times said on June 24th that concerted action in Africa could liberate one of the few remaining outposts of colonialism, not in a matter of years but months. It maintained that any system of entrenched injustice and of exploitation of man by his fellow man could be dismantled only by force. The Daily Times said that all accounts of the response of member-States of the OAU to General Gowon's challenge indicated that the general response was positive. The question now was how long it would be before such positive response was translated into action. 
position is partly due to the success of his movement which claims the control of two thirds of the territory's countryside and partly due to his own standing as a theoretician of armed struggle against colonialism.

The Portuguese role in the Nigerian war and its invasion of Guinea last year the target of which was Cabral's headquarters in Conakry - had shown Africa the danger Portugal posed to the independent African countries. The role of Portugal was also exposed in the report of the Administrative Secretary General of the OAU for the period from February 1971 to June 197123, and was dealt with by the Seventh Extraordinary Session of the Council which met in Lagos from 9 to 12 December $1970^{24}$. In addition to the increased assistance to PAIGC in Guinea-Bissau the OAU decided to establish a sub-regional office of the Liberation Committee in Conakry.

The OAU's comeback to the international scene was dramatically marked by the decision of the Assembly of Heads of State and Government on intervening in the unresolved conflict between Israel and Egypt by constituting a Committee composed of 10 Heads of State who were entrusted with the task "of seeking the best ways and means of reaching a peaceful, equitable and just solution to the grave Middle East Crisis"25. The members of the Committee, the Heads of State of Ethiopia, Cameroun, Congo, Ivory Coast, Kenya, Liberia, Mauritania, Nigeria, Senegal and Tanzania met in Kinshasa from 23-25 August 1971 and succeeded in appointing a four-man sub-committee acceptable to both Israel and Egypt. The committee composed of four heads of state - Nigeria's Major General Gowon, Cameroun's Ahidjo, Senegal's Senghor and the Zaire Republic's President Joseph Mobutu - flew first to Tel Aviv on 2 November for talks with the Israeli Government. From Israel they proceeded to Cairo where they had three days of talks with President Sadat. President Senghor emphasized that the OAU mission had no intention of acting as a mediator but only wanted to help efforts already in progress to find a peaceful solution and to set in motion a dialogue - in other words that the OAU mission was not to be regarded as a substitute for Ambassador Jarring's mission. He reminded both parties that eighty per cent of the Arabs live in Africa, and that most of the African countries maintain friedly relations both with Israel and the Arab States. The OAU mission suggested that both Israel and Egypt make compromises. Israel should inform Dr. Jarring that it is prepared to withdraw from all Egyptian and Jordanian territory conquered in the Six Day War of 1968 (the Arabs' principal objective) with named exceptions - Sharm esh-Sheikh and Jerusalem - for which special arrangements can be negotiated. Egypt, in its turn, would have to agree to peace talks without an explicit prior commitment from Israel to total withdrawal (hitherto the Arabs' principal condition for a settlement). - Both Israel and

23 Report of the Administrative Secretary General covering the period from February to June 1971 , CM/378 (Part II) quotes the following statement by Portugal's Minister of Defence, General Horacion De cu Viano Rebelo: "In the southern tropics Portugal has naval and air bases, stretching from Cape Verde Islands (off Senegal) to Portuguese Guinea and Angola, which can give support to every modern device for controlling the vast stretch of the entire Atlantic. It should not be forgotten that the whole NATO framepork can be encircled from the south and therefore our struggle in Africa is a matter of the Alliance". He is quoted as concluding: "I wish to reaffirm what I have already said on previous occasions. The Portuguese Government makes its territories and its military bases outside the NATO zone available to serve the objectives of the Alliance".

24 In its resolution ECM/Res. 18 (VII) the Council considered the intensified military activities of the Portuguese in Angola, Moçambique and Guinea Bissau and decided ato increase adequately the assistance of the OAU to the liberation movements fighting against Portuguese colonialism ${ }^{w}$ and directed the Executive Secretary of the Liberation Committee to forthwith substantially increase financial and material assistance to PAIGC to meet the new challenge from the colonial forces.

25 Resolution on the continued agression against U.A.R., AHG/Res. 66 (VIII). 
Egypt attached great importance to the OAU initiative and expressed their readiness to co-operate with the. Committee in its task. - After the visit of Presidents Mobuto of Zaire and Senghor of Senegal, General Gowon of Nigeria and President Ahidjo of Cameroun of both Israel and Egypt the OAU Committee met in Dakar in November 1971 and drew up a "Peace Plan for the Middle East" to be submitted to the United Nations. The near future will show whether the African initiative shall succeed where the Great Powers and the United Nations failed and whether President Mobutu's optimistic views on "the promising and encouraging results of the OAU mission" prove to be justified"20. More tangible results for African diplomacy were achieved by the OAU delegation which President Daddah of Mauretania in his capacity as the current Chairman of the OAU, accompanied by foreign ministers of Kenya, Zambia, Mali and Cameroun as well as by the administrative Secretary General Diallo Telli and the Executive Secretary of the OAU Liberation Committee George Magombe, led to Scandinavia in October 1971. The delegation visited Sweden, Finland, Norway, Denmark and Iceland. In Sweden, Prime Minister Olof Palme promised the OAU mission to increase the material and financial support to the African liberation movements. In Norway the OAU delegation was received by the Prime Minister Trygve Bratteli who promised an immediate grant of $\$ 100000$ to the liberation movements in Africa. The Scandinavian countries have also agreed to finance an international conference tentatively ageed to be held in Oslo in 1973 with de-colonialization and anti-apartheid as the main topics.

The point is, of course, that whether the Organisation of African Unity will succeed in the attainment of its goals, namely: liberating the continent from the last vestiges of colonialism and bringing about changes in the racial policies of South Africa and Rhodesia, either peacefully or by force, depends far more on the support it can secure from abroad than from within Africa itself. And Africa has also learned that the expression of sympathies and moral support, though valuable, are no longer sufficient to alleviate its problems unless they are supported by measures at governmental level. Only a decision by the Government of Great Britain, France and Western Germany can lead to the cessation of the supply of arms to South Africa and only the decision of the NATO countries can stop arms delivery to Portugal. Similarly, only the joint diplomatic and economic pressures of, in particular, the Great Powers can make South Africa change its racial policies, bring about majority rule in Rhodesia and force Portugal to grant independence to her African colonies. While Africa never failed to win the support of public opinion at large, it lamentably lacked similar understanding on the part of the governments involved in Africa's confrontation with its enemies. The British agreement with Rhodesia of 24 November, by virtue of which government in Rhodesia remains in the hands of the white minority for at least another generation, has made it abundantly clear how little the African matters to the British Conservative Government ${ }^{27}$. Not even the resounding "no" by which the Rhodesian Africains answered the Pearce Commisson's enquiry in January - February 1972 about the acceptability of the proposed settlement seemed to have much effect on Premier Heath's Government.

26 For most recent analysis of the Middle East conflict see John de St. Jorre, "The Arab-Israeli conflict", in: Africa, an international business, economic and political monthly, London, January 1972, No. 6, pp. $23-27$. 
It is being forgotten that the future relationship between Africa and the outside world is being shaped to-day. Whether large scale racial conflict between independent Africa and the white minority regimes of South Africa and Rhodesia and the colonial regime of Portugal will be averted, depends above all on the policies of the Western Powers. So far, their attitudes have made such conflict almost inevitable.

27 During the debate on the Rhodesian settlement in the British Parliament on 1st December 1971, Denis Healey, the former member of the Labour Government said: "If the Government goes through with this chabby charade, which is regarded by the majority of people who have examined is as a hypocritical sell-out of African interests, they will carry responsibility for the next halt century in Rhodesia around their necks like an albatross with immense damage to Britain's influence and interests throughout the their neck

On 20th December 1971, the United Nations General Assembly voted by 94 to 8 majority to reject the proposals for a Rhodesian settlement agreed between Britain and Rhodesia. The resolution described the proposals as "a flagrant violation of the right of the African peoples of Zimbabwe (Rhodesia) to self-determination and independence". It said that no settlement was acceptable unless it embodied majority rule on the bisis of one man one vote. (The Times, London, 22nd December, 1971).

In equally strong terms the agreement was also condemned by the Organisation of African Unity. For In equally strong terms the agreement was also condemned by the Organisation of African Unity. For
more details about the OAU and the Rhodesian crisis see Zdenek Cervenka, "Rhodesia five years after the Unilateral Declaration of Independence", in: Verfassung und Recht in Úbersee, Hamburg, 1971 Nr. 1, pp. 9-30. For the official text of the settlement between Great Britain and Rhodesia as outlined in the "White Paper", comments by The Times, The Guardian and Dr. Palley's analysis, see "Special Documentation Supplement on Rhodesia" issued by Africa Research Bulletin, London, 1971, 15th December, 20 pages. 
between legitimate and illegitimate thematic approaches to the comparison of comparable phenomena. Such legitimacy in the field of overseas comparative constitutional analysis is rooted in the principle that it can encompass those, and only those, phenomena which refer to the setting up of the decolonized peoples as sovereign states with all ensuing consequences, starting with their resolve to modernize which is an integral part of this process.

Finally, one has to enquire into the objectives which may be pursued by means of legitimate comparison of comparable phenomena. Certainly this discipline, too, seeks knowledge for its own sake in the first place. Furthermore comparative law, as is well known, tries to elaborate the concept of families of legal systems. This may apply as well to the comparison of constitutions. But certain objectives known to comparative law must be excluded: i. e., the elaboration, on an empirical basis, of a natural or world law with the aim of legal unification. The reason for this incompatibility is our last point: as comparative constitutional analysis sees the comparability (the tertium comparationis) in the similarity of a situation and of the collective problem the latter poses for a group, it cannot set itself an objective which would deprive itself of this basis. Instead, its aim is to find all constitutional topoi, to set up a corresponding deductive system, and, finally, to develop both of these aspects into a general constitutional theory. This theory should integrate into a whole all those elements existing as "constitution" in its broadest sense or which must be thought of as coming within the frame of this concept.

\section{The Organization of African Unity in the Seventies}

\section{By Zdenek ČervenKa}

The principal aims of the OAU, founded in 1963, i. e. the liberation of the remaining colonies and the liquidation of all forms of oppression have not yet been achieved. Disputes among its members, the UDI in 1965, and the series of military coups led to the withdrawal of Africa from the international scene and to its preoccupation with domestic problems. The front of independent African states was further weakened by South Africa's "new outward policy". Its essence is the creation of a "prosperity sphere" comprising all countries of Southern Africa which would provide the urgently needed market for South African exports and create a base for expansion to the north. This policy moved President Houphouet Boigny of Ivory Coast to propose the "dialogue" with South Africa: the establishment of diplomatic and economic relations as a means for "eroding apartheid". It was supported by seven or eight African countries. The 8th Summit of the OAU in Addis Ababa in June 1971 rejected the "dialogue" by a majority of 27 to 4 and made it clear that the only basis for dealing with South Africa is to be the Lusaka Manifesto of 1970. The OAU also increased assistance to the liberation movements in Africa and dispatched a mission to dissuade NATO countries from supplying arms to South Africa and Portugal. The mission also visited the Scandinavian countries who agreed to sponsor the OAU's conference on apartheid and colonialism to be held in Oslo in 1972. The OAU's comeback on the international scene was marked by its decision to intervene in the Middle East crisis by sending a committee of four Heads of State. A counter offensive against South Africa's outward policy, however, continues to be the main problem of the OAU. The weakness of its members in military and economic terms explains their 
attempts to put pressure on the Western powers to alleviate Africa's burden of apartheid and colonialism, so far without success. The British agreement with Rhodesia on 24 November 1971 illustrates the point.

\section{The Preamble of the New Draft Constitution of the People's Republic of China}

\section{By Dieter Heinzig}

In 1970, the Taiwan Intelligence Bureau managed to procure from the mainland the text of a new draft constitution of the People's Republic of China, which had been, in principle, adopted by the Second Plenary Session of the CCP Central Committee, but up to this day has not been publicly mentioned in Communist China. This first text did not include a preamble, however, and turned out to be incomplete insofar. In the meantime, the Taipei journal "Chung-kung yen-chiu" (Studies on Chinese Communism) published two versions of this missing preamble, which are nearly identical. The present article supplies a German translation of the preamble together with an introductory comment.

Compared with the 1954 constitution, the new preamble is marked generally by a more revolutionary and militant keynote thus reflecting the spirit of the Cultural Revolution. Some of its passages are verbatim quotations from Mao Tse-tung or Lin Piao, others are taken from the Chinese polemics against the Soviet Union. The inclusion of the term "social imperialism" must be regarded as a constitutional confirmation of anti-sovietism. The use of the wording "continuous" instead of "permanent revolution", when describing the domestic scene, possibly could evidence a victory won by a Lin Piao faction over a Ch'en Po-ta faction in the fall of 1970. After Lin Piao has disappeared from the political stage, the new draft constitution will have to be changed before being adopted by the forthcoming IVth National People's Congress meanwhile postponed to a still unknown date. For Lin Piao is mentioned both in the draft preamble and in the draft constitution itself in his capacity as Vice-Chairman of the Party's Central Committee and as Mao Tse-tung's successor.

\section{Agrarian Reform and Cooperatives in a Developing Country: The Case of Egypt}

\section{By Bassam Tibi}

The above study begins with an analysis of the terms agrarian reform and agrarian cooperative. The analysis is oriented on the socialeconomic situation of underdeveloped countries. It is shown that the agrarian question is of central importance because these countries are predominately agrarian regions. The vague assertation of agrarian reform to be either technical modernization, or simple redistribution of the land is critizised. An agrarian reform can only be effective when it contains both these aspects. The development of underdeveloped agrarian regions necessitates an agrarstructural transformation, but such transformation can only take place when the dominating ruling structures that could prevent it have been overcome.

These historically oriented thesises can be verified in the case of Egypt. The land laws and the agrarian question connected to them must be analyzed in order to 